\title{
The perspective of al-Sunnah al-Nabawiyyah to handle the outbreak of a Pandemic Disease
}

\author{
Muhammad Masruria, Faisal Husen Ismail ${ }^{b}$ Abd Shakor bin Borham ${ }^{c}$, Arwansyah Kirin ${ }^{\mathrm{d}}$, Muhammad \\ Misbah $^{\mathrm{e}}$, Masykur $^{\mathrm{f}}$, and Imam Tabroni ${ }^{\mathrm{g}}$

Article History: Received: 11 January 2021; Accepted: 27 February 2021; Published online: 5 April 2021

\begin{abstract}
Infectious diseases that have reached the stage of pandemic are dangerous diseases because of the level of invection quickly and spread throughout the world. This disease infects anyone without exception. Although infectious diseases already exist and have been known since the time of the Prophet Muhammad PBUH, but there are still many people who do not understand that the method of the Prophet PBUH is one of the best methods to stop the infection and the chain of pandemic diseases. This article aims to describe some of the methods used by The Prophet while facing the spread of Plague and Leprosy infection in the community. Study of the text and the content of the approach of the Prophet PBUH to handle and stop the infectious diseases that reach pandemic levels. Among the methods are; a ban on entering the affected area and a ban on leaving it, stay at home, be patient and believe in the provisions of Allah SWT, did not meet the patient, keep distance with others, strive to find healing and believing that every disease has a cure, The teachings and guidance of the Prophet SAW is expected as a guide for Muslims when experiencing the outbreak of pandemic disease from time to time.
\end{abstract}

Keywords: The perspective, al-sunnah, disease, pandemic, method.

\section{Introduction}

The term pandemic refers to an outbreak that strikes in a larger scope and is not limited to a particular community or district. This infectious pandemic has passed epidemic levels. This pandemic will threaten a wider area such as a state, country, continent or maybe even the whole world (Miquel Porta 2014). Pandemics is the spread of new diseases around the world. According to the World Health Organization (WHO), the pandemic began when three conditions were met, namely the emergence of new diseases in the wider population in infecting humans, causing serious illness and even death, spreading easily and rapidly worldwide. Pandemics is an epidemic of infectious diseases that has spread to large areas, affecting a large number of people. Pandemics are epidemics that occur on a scale that crosses international borders, usually affecting people on a world scale and it must also be contagious. With very high levels of infection, this epidemic needs to get very serious treatment. Pandemics is a disease that has existed since the beginning of human civilization. Among the earliest pandemic diseases to infect humans was Antonine Plague which was between 165 AD. This pandemic has sacrificed five million human lives. The Jastinian pandemic is one of the infectious diseases that causes the turmoil and unrest of the world community. the epidemic has claimed 30 to 50 million human lives. The pandemic spread throughout the world between 541 and 542 AD. Between 1347-1352 AD, the pandemic of The Black Death spread and infected millions of people in Europe, Africa and Asia. This disease has claimed more than 75 million lives. The Spanish Flu pandemic was one of the pandemics that occurred in the 20th century. This pandemic has spread and infected almost the whole of Europe and spread rapidly throughout the world between 1918 and 1920 AD. The disease has claimed 50 million lives. Currently, the entire human race around the world has been shocked by the COVID-19 pandemic. The pandemic has infected millions of people around the world. According to Worldometer reports, as of July 30, 2020, the Covid-19 pandemic has infected 17,171,005 people and claimed 669,242 human lives. (Michael S. Rosenwald 2020). Whereas Islamic scholar Ibn al-Athir (1987) stated that infectious diseases that reach the level of pandemic have spread and attacked the cities of Makkah, Iraq, the state of Sham and Palestine. According to the explanation of al-Zahabi (1982) that during the pandemic in the year 1055, places of worship such as mosques were closed and prayers were not established.

\section{Islamic relationship with pandemic disease}

Islam is a perfect religion because it contains various teachings and rules in daily life. Islam is very concerned about health and how to treat it. The Allah's Messenger PBUH (peace and blessings of Allah be upon him) cared about health and encouraged his ummah to be healthy and strong human beings, as in his words: 


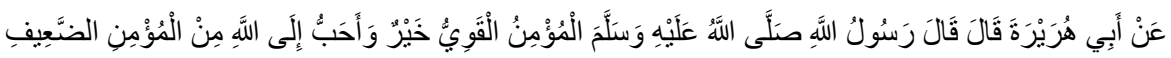

Abu Huraira reported Allah's Messenger PBUH as saying: A strong believer is better and is more lovable to Allah than a weak believer. (Sahih Muslim 4816)

Musa Shahin Lasin (2002: 10: 195) states that a strong believer is a Muslim who has a strong body and soul covering all aspects, strong in the work and practice of worship in this world and the hereafter. This hadith also gives the meaning that strong Muslim and a healthy has more ability to perform worship better. A healthy and strong body has excellent immunity to resist the onslaught of disease.

Islam encourages its people to protect themselves by using a shared approach to maintaining faith and piety to Allah SWT. Islamic teachings have always been concerned with protecting people from infectious diseases and death since the beginning of Islam. The Prophet PBUH advised his companions to appreciate their health and life. (Hamid Ashraf et. al. 2020). Al-Quran and al-sunnah provide excellent guidance for dealing with infection management and the spread of disease on a comprehensive pandemic scale.

\section{The Prophet PBUH methods to deal with the spread of pandemic infections}

Allah's Messenger PBUH as the bearer of Islamic Shari'a has given guidance to his ummah on how to deal with every disease that befalls every human being, including infectious diseases. Allah's Messenger takes an infectious disease prevention approach by not simply surrendering everything 100 percent to Allah SWT but there must be an attitude of initiative because it is to express value as a servant. Islam is very concerned about the prevention and precautionary measures of various diseases. Today there are a handful of Muslims who often express their surrender to Allah without taking into account and strive to do prevention while preserving life is one of the important foundations in the Islamic context (Sheikh Ahmad Zarqa 1989). There are also some people who say that the fear of Allah is more important than the fear of disease. Such people are among those who face the problem of confused understanding. A servant must strive to prevent and try to find a way of healing, while the rest is to surrender to the power and pleasure of Allah SWT (Masruri 2019).

In dealing with the spread of infectious diseases that reach the stage of epidemic or pandemic, Allah's Messenger PBUH gave guidance to his ummah some methods. Among the methods are the prohibition of entering and leaving the affected areas, staying at home, being patient, believing in Allah's provisions.

\section{Prohibition of Entering Areas Affected by Pandemic Outbreaks}

Allah's Messenger PBUH gave guidance to the companions by warning them not to enter the area that is the cause of pandemic disease. Companion's of The Prophet need to be vigilant and cautious in the face of an outbreak of a very dangerous disease. Among the dangerous diseases at that time was Plague. Allah's Messenger PBUH said:

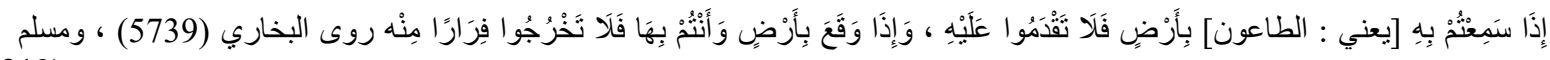
(2219)

Meaning: "If you hear that it (plague) has broken out in a land, do not go to it; but if it breaks out in a land where you are present, do not go out escaping from it.". (al-Bukhari (5739) \& Muslim (2219))

This hadith gives guidance to Muslims, that Allah's Messenger PBUH has warned his people not to enter the district or area that is being hit by a dangerous epidemic reaching the level of pandemic. Among the dangerous epidemics that reached the pandemic stage of the time was Plague disease.

In Kamus Dewan (2002) it is mentioned that the meaning of Plague is disease vomiting and frequent defecation, cholera or referred to as pandemic. In Arabic the word țā' ūn comes from the word ța ana, which has the meaning of piercing, as a metaphor for unusual pain faced by Plague patients. Plague also means an epidemic that causes high deaths; epidemic, infectious diseases, bacterial-caused outbreaks, characterized by fever, chills, and prostration, are transmitted to humans from mice with flea bites.

Some Islamic medical experts, such as al-Rāzī, al-Majūsī and Ibn Sīnā, state that the term Plague means swelling of the lymph nodes (Lawrence Conrad 1982). Al-Nawawi (1972) describes as swelling which causes no blood supply in the area until the part is dry and dead or contains pus. Al-Munawi (1972) states that in a hadith narrated by Imam Ahmad, Plague is termed as a very dangerous and deadly disease because it causes swelling of the lymph nodes. This pandemic damage the glands in the body causing swelling in the neck and armpitsIbn alQayyim (1994) states that the term Plague refers to an infectious pandemic, accompanying symptoms or signs, or the occurrence of death due to the pandemic. The effects of this pandemic cause some body members to turn black or green. Therefore, Plague disease is categorized as a pandemic. Ibn Hajar (2001) and al-Karmani (2001) state that Plague is an outbreak of a very violent and dangerous disease because it damages the entire interior of the body, it can extinguish the spirit of life in the human body.

The Prophet PBUH forbade the companions to enter the area affected by the Plague pandemic because it is very dangerous and has a very high level of infection and very fast. The purpose of the Prophet PBUH ban was also to prevent him from becoming infected with the pandemic. This prohibition is also to give peace of mind to each individual, eliminating the doubts raised by the devil. Allah SWT commands human beings to be careful and 
not to face the epidemic even if it is all on the provisions of Allah SWT (Muhammad ibn Sheikh al-Allamah Ali 2005).

Currently, the world is shocked by the pandemic of Covid-19 that is spreading rapidly around the world. To handle the spread of infection and break the chain of transmission of the pandemic of Covid-19, governments and ministries of health around the world have given the public some guidelines that need to be complied. The Malaysian government through the Malaysian National Security Council (NCO) and the Ministry of Health Malaysia $(\mathrm{MOH})$ have determined some rules that must be followed by the public to break the network of transmission of the disease.

Among the methods is that the government prohibits every individual from visiting the infected area which is categorized as a red zone, a cross-state ban and a ban on going abroad. This matter is in accordance with the order of Allah's Messenger PBUH to his ummah not to enter the area that is being hit by the epidemic. Prohibition of entering the area affected by the pandemic as perfect care from being infected with the pandemic. While entering the area affected by the pandemic is an attitude of facing the pandemic and it is contrary to reason and sharia (Ibn Qayyim 2012)

\section{Prohibition of Leaving Areas Affected by Pandemic Outbreaks}

When there is an area affected by the pandemic and the disease has spread evenly in the area, then among the preventive measures to break the network of the spread of the pandemic is to ban the exit of residents who are in the area. This is done to prevent the occurrence of a greater harm. This is as mentioned in the hadith narrated by al-Bukhari and Muslim in his sahih:

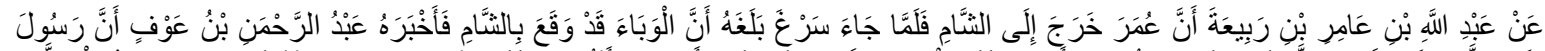

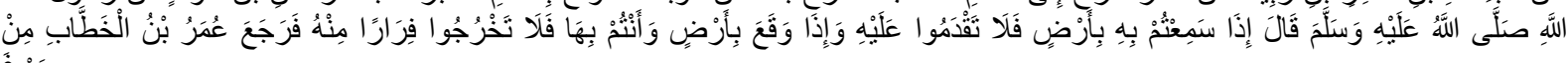

$$
\begin{aligned}
& \text { سَرَْْ مَنْ }
\end{aligned}
$$

Narrated `Abdullah bin 'Amir bin Rabi`a: `Umar ibn Al-Khattab left for Sham, and when he reached a placed called Sargh, he came to know that there was an outbreak of a pandemic (of plague) in Sham. Then `Abdur Rahman ibn `Auf told him that Allah's Messenger PBUH said, "If you hear the news of an outbreak of a pandemic (plague) in a certain place, do not enter that place: and if the epidemic falls in a place while you are present in it, do not leave that place to escape from the pandemic." So 'Umar returned from Sargh (Sahih al-Bukhari 6973 and Sahih Muslim 2219).

This hadith almost has the same meaning as the hadith above, but in the explanation of this hadith is more focused on giving a description of the ban on leaving the place affected by the pandemic.

Regarding this hadith, the previous scholars only focused on the discussion on the pleasure of receiving a test from Allah SWT. The scholars did not discuss the prohibition of the Prophet PBUH to leave the area affected by the pandemic and the Prophet PBUH instructions to remain in the place or area affected by the pandemic (Muhammad Ibn Ali 2005). Those who are positively affected by pandemics or have close contact with people who carry the disease do not move and move elsewhere which will cause the virus to spread elsewhere. But behind the command of the Prophet PBUH there is great wisdom and beneficial for every Muslim. Among the wisdom of the guidance of the Prophet PBUH is to break the network of contagious pandemic diseases. This is because through several research it was found that other people who have direct contact with people affected by the pandemic can be carriers of the pandemic disease. Preventing those in the pandemic area from going out to other areas means preventing those who are positive for the pandemic or who have a close relationship with those affected by the pandemic. Quarantine methods that have been ordered by the Prophet Muhammad PBUH to prevent the pandemic from spreading to other countries. To ensure that the order is implemented, The Prophet PBUH erected a dividing wall in the area infected with the pandemic. (Muhammad Ibn Ali 2005).

\section{Stay at Home, Be Patient and Believe in the Provisions of Allah SWT}

Currently the rest of the world is still in the process of dealing with the outbreak of covid-19. All countries in the world set rules and guidelines to curb and break the chain of transmission of the disease. Among the methods used is to implement the Movement Control Order so that people can stay at home. Islam is a religion that is very concerned about the obligation to obey and abide by the rules and laws set by the leaders. Allah SWT has said:

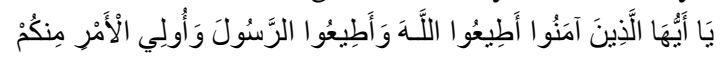

"O you who have believed, obey Allah and obey the Messenger and those in authority among you" (AnNisa:59).

By obeying the instructions of the leader, it is considered to obey the rules and laws of Allah SWT and His Messenger (al-Sya'rawi 1991). Therefore, every Muslim must obey all the instructions set by the leader as long as the instructions do not direct them to acts of immorality to Allah SWT (al-Asqalani 200). In the hadith narrated by al-Bukhari, Allah's Messenger said:

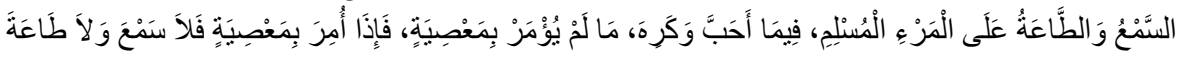

The meaning:" A Muslim has to listen to and obey (the order of his ruler) whether he likes it or not, as long as his orders involve not one in disobedience (to Allah), but if an act of disobedience (to Allah) is imposed one should not listen to it or obey it".(Saih al-Bukhari 7144 and Muslim 1839). 
When Muslims face the Plague pandemic, Allah's Messenger PBUH instructs the companions to always stay in their area or stay at home. The adherence of Muslims to the guidelines outlined by Rasulullah SAW in dealing with the pandemic environment is the key to lowering the rate of infection among the community. People who stay in the house during the pandemic period occur with patience and expect the reward and believe that everything that happens to a person is due to the provisions of Allah SWT, then he will get the reward of martyrdom (al-Ayni 2001). In the hadith narrated by al-Bukhari it is stated:

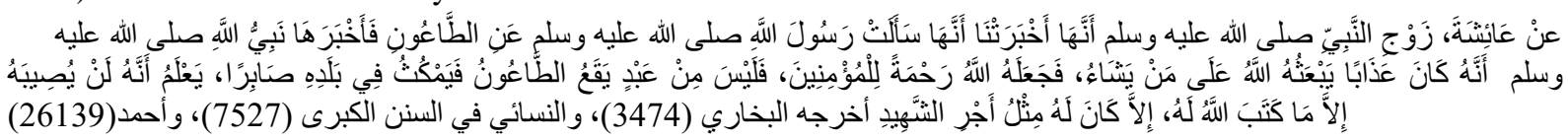

Narrated 'Aisha:

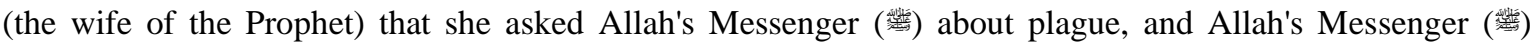
informed her saying, "Plague was a punishment which Allah used to send on whom He wished, but Allah made it a blessing for the believers. None (among the believers) remains patient in a land in which plague has broken out and considers that nothing will befall him except what Allah has ordained for him, but that Allah will grant him a reward similar to that of a martyr" (Sahih al-Bukhari 3474, al-Nasa'I 7527 and Ahmad 26139).

Al-Qastalani (1996) states that the Plague is a punishment and a torment for the infidels and rebels while for the believers as a blessing because anyone can face cholera patiently will get a reward like a martyr. The method of patience is the sunnah of the Prophet Muhammad PBUH. Every individual is expected to be patient to stay home. Patience in the sense of staying at home and refraining from going out just hoping to calm down from Allah SWT as well as by believing that the outbreak of this disease is a provision and destiny of Allah SWT. Patience does not mean giving up completely, but it must be accompanied by external and internal effort. Patience means as an attitude of refraining from feeling anxious, anxious, angry, complaining and chaos in each individual. (Ibn Qayyim al-Jawziyyah. 1998. p. 206). A person who has the nature of patience is a person who has a healthy soul and has a perfect personality. He is able to face various trials and difficult situations with pleasure and surrender completely to Allah SWT. (Othman Najati 2006, 297). With the patience to face trials or tribulations and stay at home then pandemic diseases can be controlled and the chain of transmission can be decided.

Ibn Hajar (2000) states that this hadith emphasizes the disciplinary aspect of a Muslim in dealing with disease reaches the level of pandemic. A Muslim should believe that this epidemic is a provision from Allah, they should be able to control themselves at home by being patient with all the trials that befall them and believe that everything that happens is by the will of Allah SWT. A Muslim who has all the criteria mentioned in the hadith then he is entitled to receive rewards such as the reward of martyrdom. (Muhammad ibn Ali 2005). Patience is one of the ways to achieve success. (Ibn Qayyim al-Jawziyyah 1989). The Prophet (peace and blessings of Allaah be upon him) also told his companions to stay in their homes, while those who were not healthy were placed in a special place. This in modern terms is now known as the quarantine term.

In Kamus Dewan (2002) it is mentioned that quarantine means the isolation of humans, animals or plants from abroad that are suspected of having infectious diseases in a special place. Quarantine or isolating patients in certain places is one of the effective measures to curb the spread of disease in the community. This quarantine method has long been practiced. in the history of the Islamic world, this method has also been practiced by the companions with the guidance of His Majesty PBUH. Similarly around the 14th century when the outbreak of The Blak Death hit Europe, quarantine methods were among the methods used to curb pandemic transmission due to significant effects. In the 14th to 19th centuries, several countries around the world applied quarantine to protect their people from the spread of the pandemic. During quarantine time either at home or in a special place, it is encouraged to improve the quality of worship and always pray to Allah SWT for the pandemic to pass immediately. During quarantine, all acts of worship can be done individually or in congregation with family members at home (Najmi Syahiran Mamat, Astro Awani 17 April 2020).

\section{Not Meet with Pandemic Patients}

Among the methods taught by the Prophet PBUH to his people to overcome the spread of infectious diseases is to prohibit healthy people from seeing patients. With such a ban it is possible that there is no relationship between a healthy person and a patient which is one of the causes of the contagious disease. As mentioned in the hadith narrated by al-Bukhari and Muslim in his sahih narrated Abu Huraira:

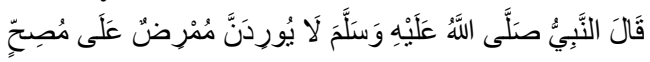

Allah's Messenger PBUH said: The cattle (sheep, cows, camels, etc.) suffering from a disease should not be mixed up with healthy cattle, (or said: "Do not put a patient with a healthy person)" (as a precaution). (Sahih alBukhari 5771 and Muslim 2221).

This hadith explains that anyone who owns a sick camel is forbidden to put on or approach a healthy camel (al'Asqalani 2000, al-'Ayni 2001). This prohibition is enforced because to disconnect the network of infections from sick camels to healthy camels. Likewise the owner of a sick camel cannot come to the healthy. (al-Kashmiri 2005). 
This hadith also teaches Muslims about the importance of health values. A healthy person so as not to come to the place of the sick person. With the ban, the spread of pandemic diseases can be stopped due to the lack of contact with other people who are still healthy. Places where patients are infected with infectious diseases should be separated from normal patients. Isolation areas should be located away from public access areas. By being placed away from the public area then this can prevent the place from being visited by the public. This is to prevent the spread of the pandemic more widely.

Islam is a religion that pays close attention to its people. The Prophet PBUH advised his people to be careful and practice preventive measures in dealing with the situation of the spread of infectious diseases (al-Nawawi 1994). In another hadith it is mentioned that the Prophet PBUH was once visited by a group of people from Bani Thaqif to swear allegiance, and one of them suffered from a contagious disease:

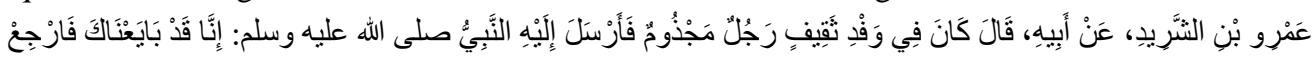

Amr b. Sharid reported on the authority of his father that there was in the delegation of Thaqif a leper. The Prophet PBUH (Peace and Blessings of Allaah be Upon Him) sent a message to him (did not come into contact with him): We have accepted your allegiance, so you may go. (Sahih Muslim 2231).

\section{Not Harmful to Others}

Pandemic outbreaks are a big problem for every individual or even for every country. Diseases that have reached this level of pandemic should not be overlooked but should be taken seriously. Therefore, for anyone who finds symptoms or signs of symptoms of the disease, then he should immediately seek treatment and can not go out to see others. When they do not care about the state of pain they face and infect others then it is considered to harm and oppress others. In the hadith from Ibn Majah it is mentioned:

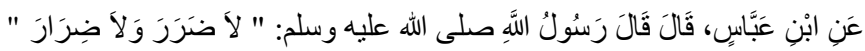

It was narrated from Ibn 'Abbas that the Messenger of Allah PBUH said: "There should be neither harming nor reciprocating harm. (Ibn Majah 2341).

According to scholars, the meaning of harm is to harm others who make mistakes or do not make mistakes (alBugha \& Misto 2007). With such distance care then physical contact with others as a cause of infection can be maintained. This hadith also warns Muslims not to do something that can bring harm to others such as when a person already knows that he is sick but still meets a healthy person without taking care of imprisonment.

Islam is very concerned about the safety of every human being who is faced with a situation that affects life and is life threatening. Islam has set some specific guidelines when dealing with emergencies such as in the event of an uncontrolled epidemic infection. When there is a clash between something that leads to maslahah and that brings harm then rejecting something harm is a priority step. A harm if not restrained, it will have a lasting effect instead of leaving maslahah (goodness) (Al-Zarqā 1989).

The actions of some members of the public who refuse to comply with government-imposed directives by going out and leaving at will can not only thwart plans to control epidemic infections, but are also potentially new causes that cause more serious harm to others. Rasulullah PBUH emphasized this matter in his words:

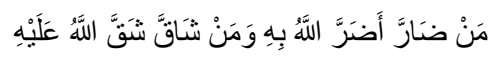

Whoever harms others, Allah (SWT) will harm him; and whoever causes hardship to other Allah will cause hardship to him (Sunan Ibn Majah 2342, Grade: Da'if).

This hadith clearly teaches lessons about warnings / harsh rebukes to anyone who harms others. It also shows that Allah SWT does not like His servants who deliberately harm others.

Allah SWT gives a parable to those who save one's life is like saving the lives of all mankind. This is as explained in the words of Allah SWT surah al-Maidah verse 32:

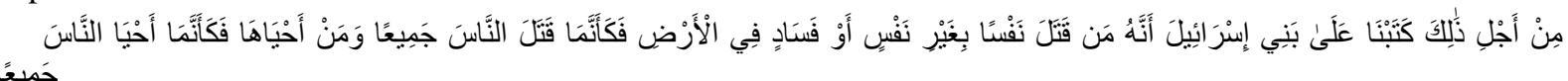

That is why We ordained for the Children of Israel that whoever takes a life — unless as a punishment for murder or mischief in the land-it will be as if they killed all of humanity; and whoever saves a life, it will be as if they saved all of humanity.

Ibn Kathir (1999) states that included in the category mentioned in this verse are those who save humanity from drowning or burning, or any destruction. This means that anyone who saves human beings from the spread of very dangerous diseases and reaches the level of pandemic is considered to save the whole human race.

\section{Avoid pandemics and keep physical distance}

Nowadays, the government has provided guidance to all citizens on the method of severing the pandemic outbreak chain among others by maintaining physical or social distance. Social imprisonment is one of the effective methods to curb the spread of pandemic. Social imprisonment was also carried out during the time of the Messenger of Allah PBUH, as mentioned in the hadith narrated by al-Bukhari that the Messenger of Allah PBUH said:

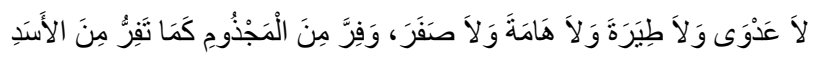


"(There is) no 'Adwa (no contagious disease is conveyed without Allah's permission). nor is there any bad omen (from birds), nor is there any Hamah, nor is there any bad omen in the month of Safar, and one should run away from the leper as one runs away from a lion. (Sahih al-Bukhari 5707).

This hadith teaches Muslims to avoid those who are infected with infectious diseases. Likewise keep a distance when meeting them. As for the rate of social imprisonment as when Umar ibn al-Khattab said to Mu'aiqib RA who was infected with leprosy by saying: اجْلِس مِنّي فَيَدَ رَنْح Sit at the length of the pole the distance from me.

Although the athar of Umar ibn al-Khattab is weak but it can be used as a guide in daily practice. If it is related to the current situation then the views and ijtihad of Umar ibn al-Khattab are very suitable to be applied to prevent the spread of pandemic outbreaks, as well as instructions from the government and the ministry of health are in line with the views of Umar ibn al-Khattab.

\section{Optimistic Will Be Healed and Trying to Find Healing}

Allah's Messenger PBUH always advised his ummah to be optimistic and confident that every disease and disaster has a cure. God sent down disease as well as medicine. in a hadith narrated by al-Buhkari, The Prophet PBUH said:

مَا أَنْزَلَ اللَُّ دَاءً إِلا أَنْزَلَ لَهُ شِفَاءً

"There is no disease that Allah has created, except that He also has created its treatment.". (Sahih al-Bukhari 5678 and Sunan Ibn Majah 3439).

Ibn Hajar (2001) stated that Allah SWT has given knowledge to the Prophet SAW about the problems faced by his people regarding the disease revealed by Allah SWT. All healing depends on the provisions of Allah SWT but for a servant is commanded to continue to seek healing until Allah gives guidance about it. In another hadith narrated by Ibn Majah, the Prophet SAW encouraged his people to always strive for healing.

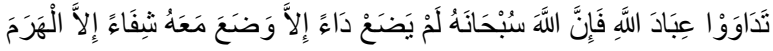

Seek treatment, O slaves of Allah! For Allah does not create any disease but He also creates with it the cure, except for old age. (Ibn Majah 3436).

With the statement from the hadith that states that every human being is encouraged to always strive to find a cure then it gives confidence that every disease that is revealed must have a cure. Allah SWT sent down the disease along with its cure. The cure for the disease will definitely be found but do not know when and only to Allah we ask for healing. An attitude of confidence in healing is also a positive value for every patient that leads to a passion for healing. With the strong spirit and soul, the patient's recovery will be faster with the permission of Allah SWT.

\section{Conclusion}

All diseases that afflict human beings are an allegation from Allah SWT. As a servant should surrender completely to Allah SWT. However, human beings also need to strive for healing and healing. Rasulullah PBUH has provided the best method for his people to deal with various diseases including infectious diseases. So is the way to deal with infectious diseases that have reached the stage of pandemic. The method taught by The Messengger of Allah PBUH proved to have a very good and significant effect in dealing with and deciding the spread of infectious pandemic diseases such as Plague. Today, where the whole world is still facing the pandemic of the Covid-19 pandemic and no cure has been found. Therefore, The Messengger of Allah PBUH guidance to the companions is very useful as one of the methods to break the chain of pandemic disease and always try to get a cure for the disease. Muslims should take seriously the teachings of The Messengger of Allah PBUH by making it a practice of his life.

\section{References}

1. Ahmad ibn Muhammad ibn Hanbal, al-Imam al-Hāfiz. 1995. Al-Musnad. Tahqīq Ahmad Muhammad Shākir. Cairo: Dar al-Hadīth.

2. al-cAsqalānī, Ibn Hajar. 2000/1421H. Fath al-Bārī Sharh sahih al-Bukhārī. Tahqīq: cAbd Qadir

3. Shaybah al-Hamdi. Bayrut: Dār al-Kutub al-Ilmiyyah.

4. al-cAyni, Badr al-Din Abi Muhammad Mahmud ibn Ahmad. 2001. cUmdah al-Qari. Bayrut: Dar al-

5. Kutub al-Ilmiyyah.

6. Al-Athir, Ali bin Muhammad bin Abdul Karim. 1987. Al-Kamil fi al-Tarikh. Bayrut: Dar al-Kutub al-

7. Ilmiyyah.

8. al-Bukhārī, al-Imam al-Hāfiz Abi cAbd Allah Muhammad ibn Ismācīl.1400 H. al-Jāmic al- Sahih.

9. Cairo: al-Matbacah al-Salafiyy

10. Al-Dhahabi, Muhammad bin Muhammad Uthman. 1982. Siyar A'lam al-Nubala. Bayrut. Muassasah

11. al-Resalah.

12. Hamid Ashraf et. al 2020.Fighting pandemics: Inspiration from Islam. Journal of the Pakistan Medical

13. Association, May 2020, Volume 70, Issue 5, 153-156

14. Ibn Qayyim al-Jawziyyah. 1998. Zad al-Macad. Bayrut: Muassasah al-Resalah. 4:36

15. Ibn Qayyim al-Jawziyyah. 2012. al-Tibb al-Nabawi. Riyad: Dar al-Salam. 
16. Al-Imam Shihab al-din Ahmad ibn Muhammad al-Qastalani. 1996, Irsyad al-Syari li Sharh Sahih al-

17. Bukhari. Bayrut: Dar al-Kutub al-Ilmiyyah.

18. Ibn Majah, al-Imām Ab̄̄ cAbd Allah Muhammad Ibn Yazīd al-Qazwayn. 1998. Sunan Ibn Mājah.

19. Tahqīq Bashār cAwwād. Bayrut: Dar al-Jayl.

20. Kamus Dewan. 2010. Kuala Lumpur: Dewan bahasa dan Pustaka. 8th edition.

21. Karmani. 1981. Sahih al-Bukhārī bi Sharh al-Karmani. Bayrut: Dar al-Ihya al-Turath al-Arabi.

22. Al-Kashmiri, Muhammad Anuar ibn Muazzam Shah. 2005. Faid al-Bari 'Ala Sahih al-Bukhari. Bayrut:

23. Dar al-Kutub al-Ilmiyyah.

24. Lawrence Conrad, "Tā̄ūn and Wabā’: Conceptions of Plague and Pestilence in Early Islam," Journal

25. of the Economic and Social History of the Orient 25, no. 3 (1982): 292

26. Michael S. Rosenwald, "History's Deadliest Pandemics, from Ancient Rome to Modern America," The

27. Washington Post, 30 July 2020, Miquel Porta, ed., A Dictionary of Epidemiology, 6th ed. (Oxford: Oxford University Press, 2014), 93, 209

28. Muhammad ibn Sheikh al-Allamah Ali bin Adam bin Musa. 2014. Bahr al-Muhit al-Thajjaj Sharh Sahih

29. Imam Muslim. Cairo: Dar Ibn Hazm.

30. Muhammad Othman Najati. 2006. al-Hadith al-Nabawi wa ilm al-Nafs. Cairo: Dar al- Suruq.

31. Muslim, al-Imām al-Hāfiz Abi al-Husayn Muslim ibn al-Hajāj al-Naysābūrī. 2006. Al-Jāmic al-Sahih.

32. Riyād: Dar al-Taybah

33. Mustafa Daib al-Bugha \& Muhyidin Misto. 2007. Al-Wafi Sharh Arbaín al-Nawawi. Damascus. Dar

34. al-Kalim al-Tayyib.

35. Musa Shahin Lasin. 2002. Fath al-Muním Sharh Sahih Muslim. Cairo: Dar al-Shuruq.

36. Al-Munawi, Muhammad Abd al-Rauf. 1972. Fayd al-Qadir Sharh al-Jamic al-Saghir. Bayrut: Dar al-

37. Macrifah.

38. Al-Nawawī, Muhyi al-Din Yahya bin al-Sharaf. 1994. Sahih Muslim bi Sharh al-Nawawi. Cairo:

39. Muassasah Qurtubah.

40. al-Nasā'̄', Abī cAbd al-Rahman ibn Shucayb. 1417 H. Sunan Al-Nasā'̄i. Tahqīq al-Albanī. Riyād: Maktabah al-Macārif.

41. Shihabuddin Abi Hafs Umar bin Ali. 2008. Al-Tawdih li Sharh Jami; al-Sahih. Qatar: Wuzarat al-

42. Awqaf wa al-Shu'un al-Islamiyyah

43. al-Tirmidhī, al-Imām al-Hāfiz Muhammad ibn cIsā Ibn Sawrah. 1417 H/1987. Sunan al-Tirmidh̄̄.

44. Tahqīq al-Albanī. Riyad: Maktabah al-Macārif.

45. Al-Zarqa, Sheikh Ahmad ibn Sheihk Muhammad. 1989. Sharh al-Qawa'id al-Fiqhiyyah. Damascus:

46. Dar al-Qalam.

47. https://www.worldometers.info/coronavirus/

48. https://www.who.int/emergencies/diseases/novel-coronavirus-2019

49. https://www.washingtonpost.com/graphics/2020/local/retropolis/coronavirus-deadliest-pandemics/

50. http://www.astroawani.com/berita-dunia/trivia-ini-5-wabak-paling-dahsyat-dalam-sejarah-manusia238709 